\title{
Virus Diagnostics and Antiviral Therapy in Acute Retinal Necrosis (ARN)
}

\author{
Peter Rautenberg ${ }^{1}$, Jost Hillenkamp², Livia Grančičova ${ }^{1}$, \\ Bernhard Nölle², Johann Roider ${ }^{2}$ and Helmut Fickenscher ${ }^{1 *}$ \\ ${ }^{1}$ Institute for Infection Medicine, \\ ${ }^{2}$ Department for Ophthalmology, Christian Albrecht University of Kiel and \\ University Medical Center Schleswig-Holstein, Kiel,
}

Germany

\section{Introduction}

Acute retinal necrosis (ARN) is a fulminant necrotizing form of retinitis of viral origin. Without treatment, ARN leads to the irreversible blindness by destruction of the retina and the optic nerve. The clinical observation was first described under the term Kirisawa uveitis (Urayama et al., 1971) while the term acute retinal necrosis was introduced by Young \& Bird (1978). The international diagnostic standard criteria were defined by Holland et al. (1994). ARN is a rare disease occurring world-wide in approximately one per 1.5-2.0 million persons per year (Muthiah et al., 2007; Vandercam et al., 2008). The rareness of this disease precludes randomized prospective clinical studies. Most observations are derived from small case series and homogenous international guidelines for therapy are still lacking. A few studies, however, allow statements on the causative agents and therapeutic principles.

Initially, herpesvirus particles were detected by electron microscopy in the retina of enucleated eyes with ARN. The causative role of herpesviruses was further established by showing local virus-specific antibody production, by demonstrating viral nucleic acids with the polymerase chain reaction (PCR), and by therapeutic success with antiviral drugs (Culbertson \& Atherton, 1993). The disease is mainly caused by the $\alpha$-herpesviruses varicella-zoster virus (VZV) or herpes-simplex virus (HSV) in $70 \%$ and $30 \%$ of the cases, respectively (e.g., Culbertson et al., 1986; Rummelt et al., 1992). While the $\beta$-herpesvirus cytomegalovirus (CMV) plays a marginal role in the pathogenesis of ARN, the role of the $\gamma$-herpesvirus Epstein-Barr virus (EBV) remains controversial. Meta-analysis shows that men are affected slightly more frequently than women (Rautenberg et al., 2009).

The early ARN diagnosis is primarily based on the virus-specific polymerase-chain reaction in punctuate fluid from the anterior chamber or the vitreous and can be supported by the detection of specific antibody titers from punctate fluid and serum using the GoldmannWitmer coefficient. Detection of virus DNA provides the basis for the early antiviral therapy which limits disease progression and risk for complications. Retinal infections by VZV or HSV are treated with aciclovir, valaciclovir, or famciclovir. Ganciclovir and valganciclovir are primarily used for the therapy of retinal CMV infections. In the case of resistance 
development against antiviral drugs, foscarnet or cidofovir are available as second-line antiviral drugs. The early specific antiviral therapy is the crucial prerequisite for the optimal clinical outcome. The pros and cons of the different application routes (oral, intraveneous, intravitreal) are discussed in order to provide sufficient drug levels in the eye. The antiviral therapy of ARN must be combined with ophthalmological and surgical procedures. Early vitrectomy has been shown to lead to a significant reduction of secondary retinal detachment. The early and combined strategy is essential for the clinical outcome of the rare ARN (Hillenkamp et al., 2009a, b, 2010; Pleyer et al., 2009).

\section{Pathogenesis, epidemiology, and clinical course of ARN}

\subsection{Viral pathogenesis}

The establishment of latency after primary infection is a common feature of herpesviruses. During latency, the entire, mostly inactive virus genome is maintained in the nuclei of host cells. The $\alpha$-herpesviruses VZV, HSV-1, and HSV-2 are characterized by their tropism for sensory neurones and epithelia. Via mucosal or cutaneous entry sites, the neurotropic herpesviruses gain access to the peripheral endings of sensory neurones. After virus uptake and axonal transport of the nucleocapsids, the virus establishes latency within approximately 14 days in the nucleus of autonomous or sensory ganglia. The viral genome persists there in circular, extrachromosomal form (Steiner et al., 2007).

In case of HSV, production of latency-associated viral transcripts seems to block virus replication and neuronal cell death. HSV-1 was shown to induce a local, CD8+ T cell-mediated, non-lytical inflammation in human trigeminal ganglia (Mott et al., 2009; Theil et al., 2003). These CD8+ T cells seem to block HSV reactivation via release of granzyme B which selectively degrades one of the regulatory proteins of HSV-1 and inhibits reactivation already in the very early phase (Khanna et al., 2004; Knickelbein et al., 2008). Thus, a well balanced equilibrium between host defense and viral immune evasion mechanisms is formed during herpesviral latency. Since virus particles are not produced during latency, virus elimination by antiviral drugs is not feasible.

The factors are not well defined which induce the reactivation of herpesvirus replication and the axonal transport of the viral nucleocapsids from the ganglion to the periphery. For HSV, ultraviolet light, neurosurgical procedures, periocular trauma and high-dosed steroid medication are known to cause reactiviation. During peripheral virus replication, clinical symptoms are observed in the region innervated by the respective sensory nerve, mostly in the form of oroacial herpes or as herpes zoster (shingles) and by far more rarely as ocular herpes (Liesegang, 2001; Lorette et al., 2006; Malvy et al., 2007).

The extremely low incidence of the ocular herpes manifestations can be explained through epidemiology as well as neuroanatomy. HSV-1 and HSV-2 have strongly different capabilities of establishing latency in trigeminal or sacral sensory ganglia and of inducing reactivation. Whereas $41 \%$ of the cases with latent trigeminal HSV-1 reactivate the virus, this occurs only in $4 \%$ of the trigeminal HSV-2 infections. In latent sacral HSV-2 infections, $89 \%$ of the patients develop recurrent genital herpes, in contrast to $25 \%$ of the cases with sacral HSV-1 latency (Lafferty et al., 1987). The rate for the symptomatic recurrence of orofacial HSV-1 is 0.12 per month in contrast to 0.001 for orofacial HSV-2 (Lafferty et al., 1987). The different rates of reactivation from different anatomical regions correspond to the mRNA prevalence 
as detected by by PCR in trigeminal ganglia, 79\% for VZV, 53\% for HSV-1, and 7\% for HSV2, respectively (Pevenstein et al., 1999). Moreover, the HSV-specific latency-associated transcripts and HSV-reactive CD8+ T cells were clearly less frequent in the neurones projecting to the ophthalmic nerve as in the other branches of the trigeminal nerve (Hüfner et al., 2009). These findings indicate that HSV reactivations occur more rarely in the eye than in the other orofacial regions.

As the latency site of $\mathrm{CMV}$, hematopoetic myelomonocytic progenitor cells are considered, from which systemic dissemination occurs via monocytes (Crough et al., 2009; Sinclair, 2008; Sinclair \& Sissons, 2006). EBV replicates primarily in the pharyngeal and tonsillar epithelium and in B cells. EBV latency is localized to quiescent B lymphocytes (Miyashita et al., 1995). Both viruses can be reactivated spontaneously or, drastically more frequently, during immunosuppression. Correspondingly, the simultaneous demonstration of DNA of differrent herpesviruses is possible in retinitis or ARN (Hasselbach et al., 2008; Hillenkamp et al., 2009a; Lau et al., 2007; Sugita et al., 2008).

The mechanisms are not yet sufficiently clarified which lead to the viral infection of the retina and finally to ARN. In a murine model, retinitis of the contralateral eye was observed within three days after intravitreal inoculation with a highly neurovirulent HSV-1 strain (Labetoulle et al., 2000). The time course of virus spread and immunohistological findings support the theory of non-synaptic virus transfer between neurones and glia cells in the chiasma opticum leading to the infection of the contralateral eye (Labetoulle et al., 2000). This is clinically relevant, since specific antiviral therapy reduces the risk for bilateral ARN (Palay et al., 1991).

For rare diseases such as herpesviral encephalitis or ARN, causative immunological defects have been discussed. In one study, plasmacytoid dendritic cells from nine ARN patients were significantly fewer than in healthy controls, as well as interferon- $\alpha$ production and CD8+ cell responses were clearly diminished. This could contribute to the impaired control of latent herpesvirus infections and subsequent development of ARN (Kittan et al., 2007).

\subsection{Epidemiology}

ARN is an extremely rare disease. Patients with endogenous uveitis had ARN in $1.3 \%$ (41 of 3060; 95\% confidence interval [CI]: 0.97-1.83\%; Goto et al., 2007). During a prospective study in Great Britain over a period of 12 months, an ARN incidence of 0.5-0.6 per million was determined (Muthiah et al., 2007). Retrospective results were obtained for the Netherlands with a similar incidence of 1.1-1.6 per million (Vandercam et al., 2008). Approximately $55 \%$ of ARN patients are men (Fig. 1; Rautenberg et al., 2009: ratio men/women: 1.18; 95\% CI: 1.061.29). In contrast, only $37.7 \%$ of the patients with orofacial herpes are men (95\% CI: $33-43 \%$; Lorette et al., 2006), while HSV seroprevalence is identical in both genders (Malkin et al., 2002).

More than 97\% (95\% CI: 96-99\%) of all ARN cases are caused by the $\alpha$-herpesviruses VZV, HSV-1, and HSV-2. VZV is the most common causative agent of ARN in approximately $70 \%$ (Fig. 2; Rautenberg et al., 2009; 95\% CI: 66-76\%) of ARN cases, followed by HSV-2 and HSV1. The age of ARN manifestation depends on the causative agent. Patients with VZVinduced ARN were $48.8 \pm 19.6$ years old (mean \pm 1 standard deviation; Fig. 3 ). The mean age of HSV-1- or HSV-2-induced ARN patients was $31.1 \pm 17.5$ or was $47.8+-19.2$ or $31.1+-17.5$ years, respectively 
author

Ganatra et al. 2000

Itoh et al. 2000

Tran etal. 2003

Lau et al. 2005

Goto et al. 2007

Muthia et al. 2007

Vanderkam et al. 2008

Hillenkamp et al. 2009

Tibbetts et al. 2010

total

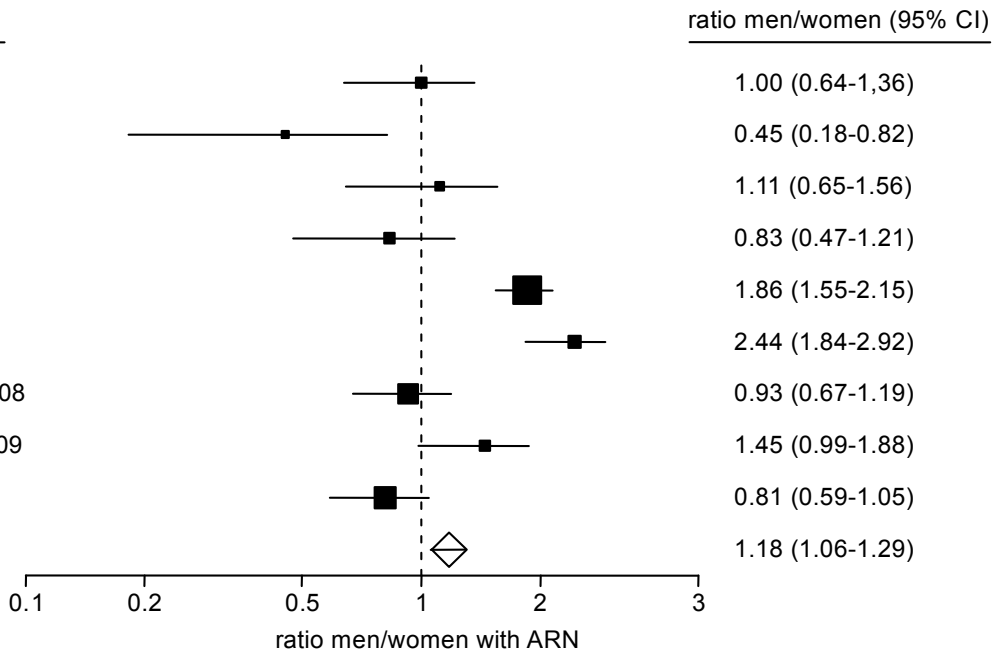

ratio men/women $(95 \% \mathrm{Cl})$
$0.45(0.18-0.82)$

$1.11(0.65-1.56)$

$.83(0.47-1.21)$

.55-2.15

$1.45(0.99-1.88)$

$.81(0.59-1.05)$

$18(1.06-1.29)$

Fig. 1. Gender distribution in ARN patients. The total value (diamond) indicates slightly more men than women ( $54 \%$ men vs. $46 \%$ women).

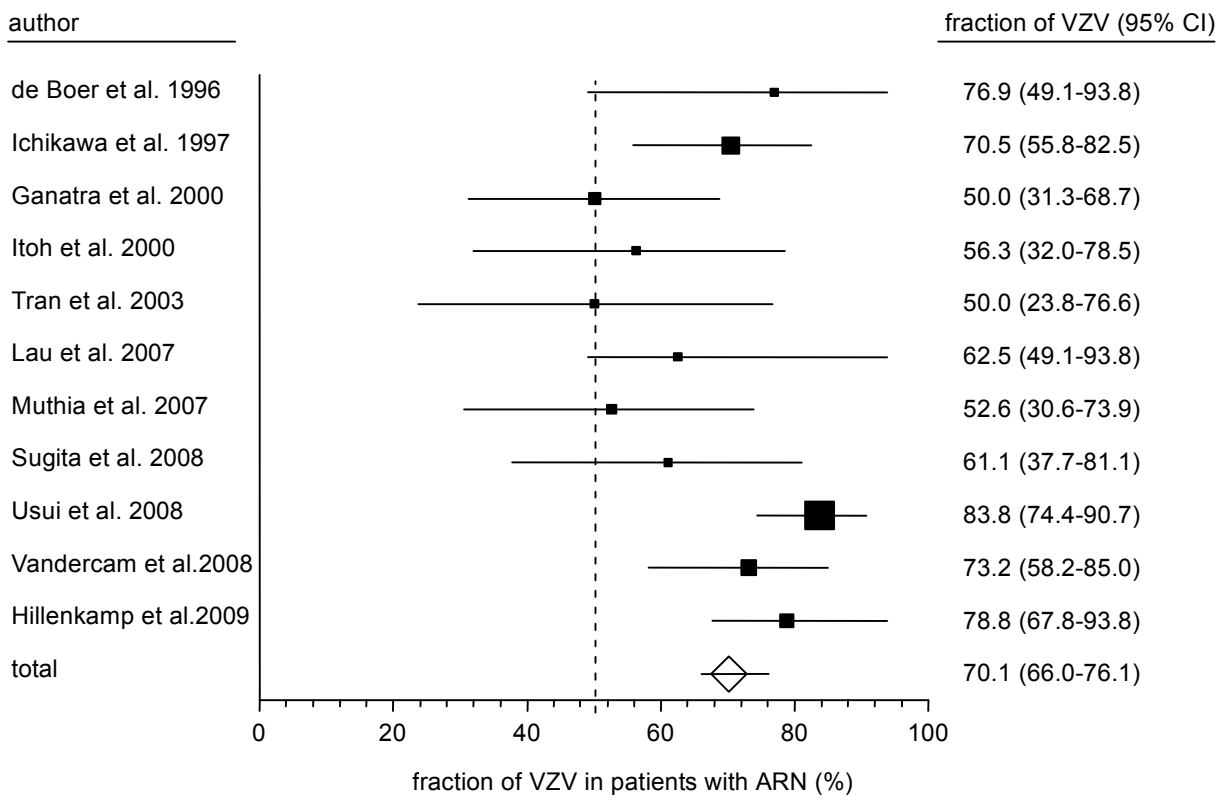

Fig. 2. Fraction of patients with VZV-induced ARN. The total value (diamond) indicates a favourite role of VZV (about 70\%) in this rare disease. 
(Ganatra et al., 2000; Itoh et al., 2000; Kychenthal et al., 2001; Rahhal et al., 1996; Schlingemann et al., 1996; Tran et al., 2003b; van Gelder et al., 2001). According to these results, a cut-off value of 36 years allows to discriminate HSV-2 from the other herpesviusinduced ARN (Fig. 3; sensitivity: 64\%; specificity: 83\%; positive predictive value at 30\% prevalence: $56 \%$; negative predictive value at $30 \%$ prevalence: $84 \%$ ). The diagnostic discrimination between ARN caused by HSV-1, HSV-2, or VZV is not highly relevant, since the therapy is identical in these cases, primarily by aciclovir.

In contrast, the virological and clinical discrimination of CMV retinitis from ARN caused by the three $\alpha$-herpesviruses is very important, since the drug of choice is ganciclovir in CMV infections. CMV as the causative agent of a viral retinitis in absence of immunsuppressive therapy in immunocompetent patients is extremely rare. To our knowledge, only four such cases were documented in the literature (Silverstein et al., 1997; Tajunisah et al., 2009; Urayama et al., 1971; Voros et al., 2006).

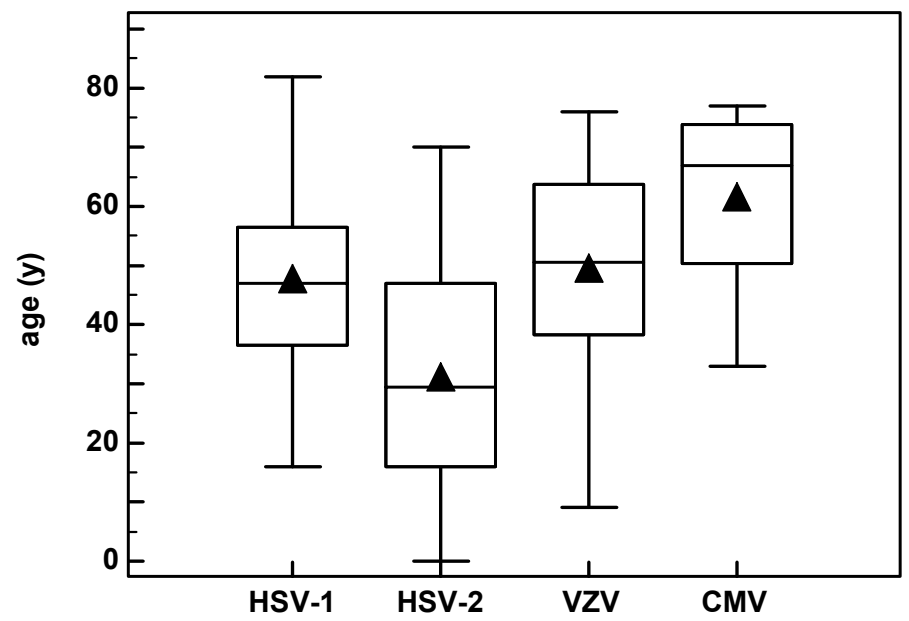

Fig. 3. Age-distribution of patients who contracted ARN by different herpesviruses. Analysis showed a significant younger age in patients who were infected by HSV-2 as compared to the other herpesviruses. The triangle within the box indicates the mean.

The controversial role of EBV for ARN was investigated in a case control study (Ongkosuwito et al., 1998). By qualitative PCR, EBV was detected in one out of 24 ocular ARN samples. However, three of 46 vitreous samples from a control group also contained EBV DNA (odds ratio: 0.62; 95\% CI: 0.06-6.34). Therefore, an association between the demonstration of EBV DNA and ARN could not be determined. Only a few studies analysed EBV DNA prevalence in ARN (Abe et al., 1996; Hillenkamp et al., 2009a; Itoh et al., 2000; Lau et al., 2007; Ongkosuwito et al., 1998; Sugita et al., 2008; Tran et al., 2003a; Yamamoto et al., 2008). In nine of 134 ARN patients, EBV DNA was detected from ocular samples. In seven of these nine ARN patients (78\%; 95\% CI: 40-96\%) VZV DNA was detected in addition to EBV by PCR (Hillenkamp et al., 2009a; Lau et al., 2007; Sugita et al., 2008). In theory, quantitative PCR methods could contribute to a clarification. However, there are no standard values for clinically relevant DNA concentrations in ocular materials and neither the diagnostic 
samples nor the PCR methods are sufficiently standardized. In summary, EBV seems to play no or -if at all- only a minor role in ARN development.

\subsection{Clinical course}

Almost 90\% of all ARN cases remain unilateral (Hillenkamp et al., 2009a; Muthiah et al., 2007; Usui et al., 2008; Vandercam et al., 2008). In approximately $10 \%$ of the patients, also the contralateral eye is affected within one to six weeks, in an extreme case after up to 34 years (Falcone \& Brockhurst, 1993; Saari et al., 1982; Schlingemann et al., 1996). A case-control study revealed that aciclovir therapy considerably reduces the risk for the contralateral eye (Palay et al., 1991). As soon as the ARN diagnosis is made, antiviral therapy should be started in order to avoid disease progression. Longer termed aciclovir prophylaxis should be considered (Cordero-Coma et al., 2007).

An increased ARN risk was discovered for the HLA alleles DQw7, DR4, and Bw62 (odds ratio: 5.2 and 7.3 respectively; Holland et al., 1989). Moreover, there is a 20-fold increased risk $(p=0.05)$ for a fulminant ARN course in the presense of the HLA DR9 allele (Matsuo \& Matsuo, 1991). Several case reports describe ARN following HSV encephalitis (Bristow et al., 2006; de la Blanchardiere et al., 2000; Gain et al., 2002; Ganatra et al., 2000; Gaynor et al., 2001; Hadden \& Berry, 2002; Kim \& Yoon, 2002; Maertzdorf et al., 2001; Pavésio et al., 1997; Yamamoto et al., 2007). In a retrospective study, thirteen of 52 patients showed infectious or non-infectious neurological diseases in the medical history (Vandercam et al., 2008). Four of eleven patients had HSV encephalitis 20.6 months (mean) prior to ARN. Two of 28 patients had VZV encephalitis 28 months (mean) before. The HSV patients showed a unilateral ARN, whereas both immunosuppressed VZV patients developed bilateral ARN. Besides various case reports, these results clearly demonstrate herpes encephalitis as a risk factor for ARN which needs attention in neurology and ophthalmology.

\section{Virus diagnostics}

\subsection{Preanalytical conditions}

Diagnostic samples can be generated in early stages by puncture of the anterior chamber, by paracentesis, by fine needle aspiration of vitreous fluid, or in advanced conditions by therapeutic pars plana vitrectomy (Winterhalter et al., 2007). The rapid PCR demonstration of virus DNA is highly important for the therapy, because specific antiviral drugs are used. Since herpesviruses and their DNA genomes are rather stable, the transport of fluid from the anterior chamber or from the vitreous does not need special precautions. Only in the case of prolonged transport times, the samples should be shipped in cooled conditions. The major diagnostic test is the PCR for herpesviral DNA for the direct demonstration of the causative agent. Virus-specific serologic tests can serve as indirect methods in order to show local antibody production at delayed time points. The major advantage of PCR testing is the low sample volume required and the independence of time-delayed immune reaction. Due to the rareness of ARN and to the critical contribution of antiviral therapy, the authors recommend the genotypic sensitivity test after demonstration of herpesvirus DNA. In case of failure of the antiviral therapy, this allows the rapid decision for either switching to cidofovir or foscarnet or for increasing aciclovir dosage in case of preserved drug sensitivity. 


\subsection{Nucleic acid diagnostics}

The clinical ARN diagnosis needs the critical validation by virus-specific PCR. During the initial stage, only PCR allows rapid and valid results. Time-delayed PCR diagnostics lead to diminished test sensitivity (de Boer et al., 1996; Knox et al., 1998). Due to the high test sensitivity of the PCR, 20-50 $\mu \mathrm{l}$ sample volume is sufficient in most cases. The PCR discrimination beween HSV-1 and HSV-2 is an established method. Real-time PCR methods allow the quantitation of viral loads in copy number per ml. Although there are no standards available for a clinically relevant virus load value, the quantitation is relevant to discriminate between the major causative agent and an additional, perhaps weak reactivation of another herpesvirus, e. g., under immunosuppression (Hasselbach et al., 2008).

\subsection{Antibody assays}

The quantitative determination of antibody titers from the anterior chamber or the vitreous in comparison to the serum levels is an indirect and supporting procedure for virus-specific diagnostics at delayed time points. For the determination of the Goldmann-Witmer coefficient (antibody index, AI; Goldmann \& Witmer, 1954), the intraocular and serum antibody titers and total IgG values are included in the following formula:

$$
\mathrm{AI}=\text { (antibody titer punctate/antibody titer serum) / (total IgG punctate/total IgG serum) }
$$

Most authors consider an AI > 2-3 an obvious indicator of intraocular antibody production (de Boer et al., 1994; Dussaix et al., 1987; Fekkar et al., 2008; Pepose et al., 1992). Serological procedures have the disadvantages that significant antibody levels can be expected only after one to two weeks and that a false-negative AI can result from massive disturbance of the blood-eye barrier. In the case of latently peristing herpesviruses, an ocular reactivation does not necessarily lead to a significant AI increase. Moreover, there are serological crossreactivites between HSV and VZV (Pepose et al., 1992). Finally, the intraocular antibody generation can be variable in immunosuppressed or HIV-infected patients (de Boer et al., 1996; Doornenbal et al., 1996; Kijlstra et al., 1989, 1990).

\section{Therapy}

\subsection{Drugs directed against $\alpha$-herpesviruses}

Aciclovir by the parenteral route is the drug of choice in severe, acute HSV or VZV infections. The acyclic guanosine derivate aciclovir is specifically activated by the viral enzyme thymidine kinase of HSV or VZV to its monophosphate. Ubiquitous cellular kinases are responsible for the conversion to aciclovir triphosphate which is a specific inhibitor for the viral DNA polymerase (de Clercq, 2004). The dosage is based on tissue culture-derived determinations of the $50 \%$-inhibitory concentration (IC50) of aciclovir against HSV-1, HSV-2, or $\mathrm{VZV}$. Due to a lack of standardisation of the assay conditions and the test viruses, these values are variable, up to several orders of magnitude. The IC50 values were 0.02 to 13.5 $\mu \mathrm{g} / \mathrm{ml}$ for HSV-1, 0.01 to $9.9 \mu \mathrm{g} / \mathrm{ml}$ for HSV-2 and 0.12 to $10.8 \mu \mathrm{g} / \mathrm{ml}$ for VZV (O'Brien \& Campoli-Richards, 1989). Due to the three hours half life of aciclovir, it should be administered intraveneously at $10 \mathrm{mg} / \mathrm{kg}$ for ten to 14 days three times daily. Consecutively, the oral application of five times daily $800 \mathrm{mg}$ for further six weeks is recommended (Blumenkranz et al., 1986; Duker \& Blumenkranz, 1991; Morse \& Mizoguchi, 1995; Palay et al., 1991). This 
recommendation is based on a case-control study in which most of the bilateral ARN cases ocurred within a period of six weeks and in which $90 \%$ of the bilateral ARN cases could have been avoided by aciclovir therapy (Palay et al., 1991). After the start of the antiviral therapy, new lesions should not occur from the second day on. From the fourth or fifth day on, the retinal infiltrates should show a tendence for regression. After one month, a complete remission should be achieved (Blumenkranz et al., 1986). If this is not accomplished, either there was an insufficient drug dosage, or antiviral resistance has developed which is more frequently seen in immunosuppressed patients. The side effects of aciclovir are rather weak and rare and may include mild serum creatinine increase, nausea, and vomiting. Presently, the authors recommend aciclovir as first-line therapy of choice in the early phase of the disease. This is based on the long-termed experience with this drug. Moreover, this excludes influences from the intra- and interindividual variability of the oral bioavailability of valaciclovir (Hillenkamp et al., 2009a, b, 2010; Phan et al., 2003). The management of ARN by antiviral drugs has been summarized in a recent review article (Tam eta al., 2010).

Valaciclovir is the valyl ester of aciclovir, which is quickly taken up into enterocytes after oral administration via enteric aminoacid transport systems and which is then hydrolyzed to the active prodrug aciclovir (Granero \& Amidon, 2006; Katragadda et al., 2005). The oral bioavailability of valaciclovir of $54 \%$ is three times higher than that of aciclovir (Soul-Lawton et al., 1995). When $1000 \mathrm{mg}$ valaciclovir were administered three times daily, aciclovir serum levels of $4.41 \mu \mathrm{g} / \mathrm{ml}$ and aciclovir levels in the vitreous of $1.03 \mu \mathrm{g} / \mathrm{ml}$ were reached. These concentrations are in the IC50 range for most HSV or VZV isolates. The lower peak concentrations during oral in comparison to parenteral aciclovir therapy minimize the risk for renal side effects (Huynh et al., 2008).

Famciclovir is an orally available di-acetyl derivate of penciclovir. By deacetylation, famciclovir is metabolized in the liver to the active prodrug penciclovir which is secreted without modification by the kidneys (Chakrabarty et al., 2004). The oral bioavailability of famciclovir is $77 \%$ and, thus, approximately 1.5 -fold higher than that of valaciclovir (Soul-Lawton et al., 1995) or 3.4-fold higher than that of aciclovir (15-30\%; Fletcher \& Bean, 1985). By oral administration of $500 \mathrm{mg}$ every eight hours, intravitreal penciclovir concentrations of 1.2 $\mu \mathrm{g} / \mathrm{ml}$ can be reached (Chong et al., 2009), which is appropriate for the therapy of nonresistant HSV-1, HSV-2, or VZV strains. In some single case reports, famciclovir was active against aciclovir-resistant VZV strains (Figueroa et al., 1997). However, the main reasons for aciclovir resistance are mutations of the viral thymidine kinase gene, which would typically also result in penciclovir resistance.

Based on case reports with orally available prodrugs of aciclovir (Emerson et al., 2006; Savant et al., 2004), a pilot study was performed with ten eyes of eight patients (Aizman et al., 2007). Under the oral therapy with $1 \mathrm{~g}$ valganciclovir or $500 \mathrm{mg}$ famaciclovir three times daily, the ARN regression occurred within six days and the maximal improvement within 17 days without any case of contralateral ARN during further 36 weeks of observation. As long as randomized prospective studies on the efficiency of the oral aciclovir alternatives are not yet available, the initial standard therapy should be performed with intraveneous aciclovir, only.

Resistance mutations. Especially in immunosuppressed patients, resistance development against aciclovir is observed frequently. However, underdosage must be excluded first. Under optimal conditions, the genotypic viral resistance can be determined by DNA PCR 
and sequencing of the viral gene for thymidine kinase and by the sequence comparison with known resistant viruses within a few days. The cultural resistance testing depends on the successful virus isolation. This procedure is slower, hardly standardized and only possible in a few reference laboratories. More than $90 \%$ of the resistance cases result from mutations of the thymidine kinase gene. In case of resistance, cidofovir and foscarnet are usually the only available alternatives, since their activity mechanism is independent of the viral thymidine kinase. Both drugs can also be used for ganciclovir-resistant CMV strains.

Cidofovir is an acyclic nucleosid phosphonate with a broad activity spectrum against DNA viruses (de Clercq \& Holý, 2005). Host cell kinases convert cidofovir to the active diphosphonyl ester which acts as a competitive inhibitor of the viral DNA polymerases and induces viral DNA chain termination. Aciclovir-resistant virus strain may be susceptible to cidofovir. The drug is administered intraveneously since its oral bioavailability is only $5 \%$. The peculiarity of cidofovir is its very high intracellular half-life time of more than 24 hours (de Clercq \& Holý, 2005). Cidofovir should be used only as a drug of second choice. It is infused in a dose of $5 \mathrm{mg} / \mathrm{kg}$ over one hour once weekly in two weeks. For maintenance, the infusion is then repeated every second week in the same dosage. The major disadvantage of cidofovir is its nephrotoxicity which is due to the accumulation of this drug by an anion transporter system of the proximal tubuli of the renal cortex (Ho et al., 2000). Since cidofovir is renally secreted, it must be combined with probenecid for kidney protection.

Foscarnet. In the case of a proven resistance against aciclovir, ganciclovir, or their prodrugs, foscarnet is the drug of choice. Foscarnet is a pyrophosphate analogon which occupies the pyrophosphate binding site on the herpesviral DNA polymerase and inhibits the release of pyrophosphate from the terminal nucleotide triphosphate of the growing viral DNA chain (Biron, 2006). Due to the very low oral bioavailability of $20 \%$, the drug is administered by large-volume intraveneous infusions. Foscarnet is used in a dosage of $60 \mathrm{mg} / \mathrm{kg}$ every eight hours. Foscarnet is renally eliminated without any metabolic modification. In patients with diminished renal function, the dosis must be adjusted to the creatinine clearance value. The major side effect of foscarnet is its nephrotoxicity.

Intravitreal application. Vitreous concentrations of aciclovir following intravenous administration has not yet been tested on a broad basis. Therefore, in patients, who do not respond to intravenous therapy, the intravitreal application of the respective antiviral drug should be considered in order to rapidly achieve high concentrations of the drug and, thus, an improved prognosis (Hillenkamp et al., 2009a, 2010; Scott et al., 2002; Velez et al., 2001; Zambarakji et al., 2002). This strategy allows high intraocular drug levels under reduced systemic exposure. Studies on repeated injections are not yet available.

\subsection{Drugs directed against cytomegalovirus}

In contrast to the $\alpha$-herpesviruses, CMV lacks a viral thymidine kinase. Presently, four drugs are licensed for CMV therapy: ganciclovir, valganciclovir, cidofovir, and foscarnet. All of them target the viral DNA polymerase and inhibit the viral DNA synthesis.

Ganciclovir and its orally available valyl ester-derivate valganciclovir are the drugs of first choice for the therapy of CMV-induced diseases (de Clercq, 2004). The substances are monophosphorylated in CMV-infected cells by the CMV-specific protein kinase UL97, and subsequently triphosphorylated by cellular kinases. The incorporation of the acyclic 
ganciclovir triphosphate into the growing viral DNA chain results in the blockade of polymerase translocation (Reid et al., 1988). Since the oral bioavailability of ganiclovir is only approximately 5\%, the drug should be administered intravenously during the ganciclovir disease. In most cases, $10 \mathrm{mg} / \mathrm{kg}$ i.v. daily should be sufficient for the CMV therapy in ARN cases. The oral bioavailability of valganciclovir is approximately $60 \%$. A daily dose of $900 \mathrm{mg}$ will yield serum concentrations comparable to $5 \mathrm{mg} / \mathrm{kg}$ intraveneous ganciclovir or a 1,7-fold serum concentration in comparison to $1000 \mathrm{mg}$ oral ganciclovir (Cvetković \& Wellington, 2005). The major side effect of systemic ganciclovir therapy is neutropenia in approximately $8 \%$ of the patients. Therefore, ganciclovir therapy needs the regular control of blood counts, as well as the surveillance of renal function (Paya et al., 2004).

UL97 resistance mutations. Mutations of the UL97 protein kinase of CMV are the major cause of resistance against ganciclovir and its derivates. The resistence is determined genotypically by sequencing if the viral genes for the UL97 kinase and for the DNA polymerase. The most frequent ganciclovir resistence mutations in UL97 (codons 460, 520, 590-607) inhibit ganciclovir phosphorylation which is the prerequsite for antiviral activity (Chou et al., 2008). The activity of cidofovir and foscarnet is independent of the protein kinase UL97 and appropriate for the therapy of many DNA viruses.

\subsection{Differential diagnosis}

During the early disease stages, additional infectious agents, rheumatological disorders, autoimmune uveitis, or intraocular lymphomas have to be considered (Table 1). Whereas

\begin{tabular}{lll}
\hline Disease & Diagnosis & First-line therapy \\
\hline ARN by varicella zoster virus & PCR & aciclovir \\
ARN by herpes simplex virus & PCR & aciclovir \\
ARN by cytomegalovirus & PCR & ganciclovir \\
ARN by Epstein-Barr virus & PCR & not available \\
\hline Progressive outer retina necrosis & PCR, serology & dependent on the agent \\
Cytomegalovirus retinitis & PCR & ganciclovir \\
Lyme borreliosis & serology, PCR & cephalosporin \\
Syphilis & serology & penicillin \\
Toxoplasmosis retinitis & serology, PCR & pyrimethamine/sulfonamide \\
Tuberculosis & culture, PCR & antimycobacterial therapy \\
Endogeneous endophthalmitis & culture, PCR & dependent on the agent \\
Bacterial eye infection & culture, PCR & dependent on the agent \\
Fungal eye infection & culture, PCR, Antigen & Candida: Fluconazol \\
& & Aspergillus: Voriconazol \\
\hline Behçet's disease & clinic, pathergia test & immunosuppression \\
Sarcoidosis & histology & immunosuppression \\
Idiopathic chorioretinitis & exclusion diagnosis & immunosuppression \\
Idiopathic retinovasculitis & exclusion diagnosis & immunosuppression \\
\hline Intraocular lymphoma & cytology, tumor genetics & radiochemotherapy \\
\hline
\end{tabular}

Table 1. Differential diagnosis of acute retinal necrosis. 
the start of ARN therapy is critical for the outcome the initiation of the therapy for most alternative causes is by far less urgent. Due to the similar clinical appearance, toxoplasmosis chorioretinitis is an important differential diagnosis (Balansard et al., 2005; Hasselbach et al., 2008; Moshfeghi et al., 2004). An ocular manifestation of syphilis can show many different symptoms and can mimick various diseases. In contrast to ARN, CMV retinitis shows weak inflammation signs in the anterior chamber and the vitreous. Patients with CMV retinitis are usually infected with human immunodeficiency virus (HIV) with less than 50 CD4+ T cells/ $\mu$ l. CMV retinitis is resistant to aciclovir therapy. Therefore, the early PCR test for virus DNA is necessary.

Finally, progressive outer retina necrosis (PORN) forms another differential diagnosis, which was mainly described in HIV patients (Forster et al., 1990). Typically, the outer retinal layers are primarily affected multifocally, while the inner retinal layers are less concerned. In contrast to ARN, there is no vasculitis component. The course of PORN disease is extremely rapid, spreading to the the deep retinal layers and leading to retinal detachment. Patients with PORN usually show coinfection with HIV and VZV.

\section{Conclusion}

ARN occurs in up to one per million persons per year. The virus-caused disease remains unilateral in approximately $90 \%$ of the cases. Without treatment, ARN shows poor prognosis. The immediate calculated antiviral therapy by aciclovir or its prodrugs is justified, since approximately $70 \%$ of the cases are caused by VZV and $30 \%$ by HSV. The causative role of EBV remains controversial; often, EBV reactivation occurs concomitantly with VZV reactivation. While EBV reactivation cannot be treated efficiently, aciclovir is appropriate for VZV and HSV reactivations. The very rare case of CMV in ARN is an indication for ganciclovir or its prodrug. The virus-specific DNA PCR test from fluid of the anterior chamber or the vitreous provides the critical indication for the specific therapy. Disease progression and complications rates can be limited by additional immediate conservative and surgical therapy.

\section{Acknowledgements}

The scientific work underlying this manuscript was supported in part by the Deutsche Forschungsgemeinschaft (Bonn), the Excellence Cluster Inflammation at Interfaces (Kiel), and the Varicella-Zoster Virus Research Foundation (New York).

\section{References}

Abe, T.; Tsuchida, K.; Tamai, M. (1996). A comparative study of the polymerase chain reaction and local antibody production in acute retinal necrosis syndrome and cytomegalovirus retinitis. Graefes Archive for Clinical and Experimental Ophthalmology, Vol. 234, No. 7, pp. 419-424

Aizman, A.; Johnson, M. W.; Elner, S. G. (2007). Treatment of acute retinal necrosis syndrome with oral antiviral medications. Ophthalmology, Vol. 114, No. 2, pp. 307-312

Balansard, B.; Bodaghi, B.; Cassoux, N.; Fardeau, C.; Romand, S.; Rozenberg, F.; Rao, N. A.; Lehoang, P. (2005). Necrotising retinopathies simulating acute retinal necrosis syndrome. British Journal of Ophthalmology, Vol. 89, No. 1, pp. 96-101 
Biron, K. K. (2006). Antiviral drugs for cytomegalovirus diseases. Antiviral Research, Vol. 71, No. 2-3, pp. 154-163

Blumenkranz, M. S.; Culbertson, W. W.; Clarkson, J. G.; Dix, R. (1986). Treatment of the acute retinal necrosis syndrome with intravenous acyclovir. Ophthalmology, Vol. 93, No. 3, 296-300

Bristow, E. A.; Cottrell, D., G.; Pandit, R. J. (2006). Bilateral acute retinal necrosis syndrome following herpes simplex type 1 encephalitis. Eye (London), Vol. 20, No. 11, pp. 1327-1330

Chakrabarty, A.; Tyring, S. K.; Beutner, K.; Rauser, M. (2004). Recent clinical experience with famciclovir, a "third generation" nucleoside prodrug. Antiviral Chemistry and Chemotherapy, Vol. 15, No. 5, pp. 251-253

Chong, D. Y.; Johnson, M. W.; Huynh, T. H.; Hall, E. F.; Comer, G. M.; Fish, D. N. (2009). Vitreous penetration of orally administered famciclovir. American Journal of Ophthalmology, Vol. 148, No. 1, pp. 38-42

Chou, S. (2008). Cytomegalovirus UL97 mutations in the era of ganciclovir and maribavir. Reviews in Medical Virology, Vol. 18, No. 4, pp. 233-246

Cordero-Coma, M.; Anzaar, F.; Yilmaz, T.; Foster, C. S. (2007). Herpetic retinitis. Herpes, Vol. 14, No. 1, pp. 4-10.

Crough T, Khanna R (2009) Immunobiology of human cytomegalovirus: from bench to bedside. Clinical Microbiology Reviews, Vol. 22, No. 1, pp. 76-98

Culbertson, W. W.; Atherton, S. S. (1993). Acute retinal necrosis and similar retinitis syndromes. International Ophthalmology Clinics, Vol. 33, No. 1, pp. 129-143

Culbertson, W. W.; Blumenkranz, M. S.; Pepose, J. S.; Stewart, J. A.; Curtin, V. T. (1986). Varicella zoster virus is a cause of the acute retinal necrosis syndrome. Ophthalmology, Vol. 93, No. 5, 559-569

Cvetković, R. S.; Wellington, K. (2005). Valganciclovir: a review of its use in the management of CMV infection and disease in immunocompromised patients. Drugs, Vol. 65, No. 6, pp. 859-878

de Boer, J. H.; Luyendijk, L.; Rothova, A.; Baarsma, G. S.; de Jong, P. T.; Bollemeijer, J. G.; Rademakers, A. J.; van der Lelij, A.; Zaal, M.J.; Kijlstra, A. (1994). Detection of intraocular antibody production to herpesviruses in acute retinal necrosis syndrome. American Journal of Ophthalmology, Vol. 117, No. 2, 201-210

de Boer, J. H.; Verhagen, C.; Bruinenberg, M.; Rothova, A.; de Jong, P. T.; Baarsma, G. S.; van der Lelij, A.; Ooyman, F. M.; Bollemeijer, J. G.; Derhaag, P. J.; Kijlstra, A. (1996). Serologic and polymerase chain reaction analysis of intraocular fluids in the diagnosis of infectious uveitis. American Journal of Ophthalmology, Vol. 121, No. 6, pp. 650-658

de Clercq, E. (2004). Antiviral drugs in current clinical use. Journal of Clinical Virology, Vol. 30, No. 2, pp. 115-133

de Clercq, E.; Holý, A. (2005). Acyclic nucleoside phosphonates: a key class of antiviral drugs. Nature Reviews Drug Discovery, Vol. 4, No. 11, pp. 928-940

de la Blanchardiere, A.; Rozenberg, F.; Caumes, E.; Picard, O.; Lionnet, F.; Livartowski, J.; Coste, J.; Sicard, D.; Lebon, P.; Salmon-Cèron, D. (2000). Neurological complications of varicella-zoster virus infection in adults with human immunodeficiency virus infection. Scandinavian Journal of Infectious Diseases, Vol. 32, No. 3, pp. 263-269 
Doornenbal, P.; Seerp Baarsma, G.; Quint, W. G.; Kijlstra, A.; Rothbarth, P. H.; Niesters, H. G. (1996). Diagnostic assays in cytomegalovirus retinitis: detection of herpesvirus by simultaneous application of the polymerase chain reaction and local antibody analysis on ocular fluid. British Journal of Ophthalmology, Vol. 80, No. 3, pp. 235-240

Duker, J. S.; Blumenkranz, M. S. (1991). Diagnosis and management of the acute retinal necrosis (ARN) syndrome. Survey of Ophthalmology, Vol. 35, No. 5, pp. 327-343

Dussaix, E.; Cerqueti, P. M.; Pontet, F.; Bloch-Michel, E. (1987). New approaches to the detection of locally produced antiviral antibodies in the aqueous of patients with endogenous uveitis. Ophthalmologica, Vol. 194, No. 2-3, pp. 145-149

Emerson, G. G.; Smith, J. R.; Wilson, D. J.; Rosenbaum, J. T.; Flaxel, C. J. (2006). Primary treatment of acute retinal necrosis with oral antiviral therapy. Ophthalmology, Vol. 113, No. 12, pp. 2259-2261

Falcone, P. M.; Brockhurst, R. J. (1993). Delayed onset of bilateral acute retinal necrosis syndrome: a 34-year interval. Annals of Ophthalmology, Vol. 25, No. 10, pp. 373-374

Fekkar, A.; Bodaghi, B.; Touafek, F.; Le Hoang, P.; Mazier, D.; Paris, L. (2008). Comparison of immunoblotting, calculation of the Goldmann-Witmer coefficient, and real-time PCR using aqueous humor samples for diagnosis of ocular toxoplasmosis. Journal of Clinical Microbiology, Vol. 46, No. 6, pp. 1965-1967

Figueroa, M. S.; Garabito, I.; Gutierrez, C.; Fortun, J. (1997). Famciclovir for the treatment of acute retinal necrosis (ARN) syndrome. American Journal of Ophthalmology, Vol. 123, No. 2, pp. 255-257

Fletcher, C.; Bean, B. (1985). Evaluation of oral acyclovir therapy. Drug Intelligence and Clinical Pharmacology, Vol. 19, No. 7-8, pp. 518-524

Forster, D. J.; Dugel, P. U.; Frangieh, G. T.; Liggett, P. E.; Rao, N. A. (1990). Rapidly progresssive outer retinal necrosis in the acquired immunodeficiency syndrome. American Journal of Ophthalmology, Vol. 110, No. 4, pp. 341-348

Gain, P.; Chiquet, C.; Thuret, G.; Drouet, E.; Antoine, J. C. (2002). Herpes simplex virus type 1 encephalitis associated with acute retinal necrosis syndrome in an immunocompetent patient. Acta Ophthalmologica Scandinavica, Vol. 80, No. 5, pp. 546-549

Ganatra, J. B.; Chandler, D.; Santos, C.; Kuppermann, B.; Margolis, T. P. (2000). Viral causes of the acute retinal necrosis syndrome. American Journal of Ophthalmology, Vol. 129, No. 2, pp. 166-172

Gaynor, B. D.; Wade, N. K.; Cunningham, E. T. Jr. (2001). Herpes simplex virus type 1 associated acute retinal necrosis following encephalitis. Retina, Vol. 21, No. 6, pp. 688690

Goldmann, H.; Witmer, R. (1954). Antibodies in the aqueous humor. Ophthalmologica, Vol. 127, No. 4-5, pp. 323-330

Goto, H.; Mochizuki, M.; Yamaki, K.; Kotake, S.; Usui, M.; Ohno, S. (2007). Epidemiological survey of intraocular inflammation in Japan. Japanese Journal of Ophthalmology, Vol. 51, No. 1, pp. 41-44

Granero, G. E.; Amidon, G. L. (2006). Stability of valacyclovir: implications for its oral bioavailability. International Journal of Pharmaceutics, Vol. 317, No. 1, pp. 14-18

Hadden, P. W.; Barry, C. J. (2002). Herpetic encephalitis and acute retinal necrosis. New England Journal of Medicine, Vol. 347, No. 24, p. 1932

Hasselbach, H. C.; Fickenscher, H.; Nölle, B; Roider, J. (2008) Atypical ocular toxoplasmosis with concomitant ocular reactivation of varicella-zoster virus and cytomegalovirus 
in an immunocompromised host. Klinische Monatsblätter für Augenheilkunde, Vol. 225, No. 3, pp. 236-239

Hillenkamp, J., Nölle, B., Bruns, C., Rautenberg, P., Fickenscher, H., Roider, J. (2009a). Acute retinal necrosis: clinical features, early vitrectomy, and outcomes. Ophthalmology, Vol. 116, No. 10, pp. 1971-1975

Hillenkamp, J., Nölle, B., Bruns, C., Rautenberg, P., Fickenscher, H., Roider, J. (2010). Acute retinal necrosis: clinical features, early vitrectomy, and outcomes. Author reply. Ophthalmology, Vol. 117, No. 8, pp. 1660-1661

Hillenkamp, J., Nölle, B., Rautenberg, P., Fickenscher, H., Roider, J. (2009b) Acute retinal necrosis: Clinical features and therapy options. Ophthalmologe, Vol. 106, No. 12, pp. 1058-1064

Ho, E. S.; Lin, D. C.; Mendel, D. B.; Cihlar, T. (2000). Cytotoxicity of antiviral nucleotides adefovir and cidofovir is induced by the expression of human renal organic anion transporter 1. Journal of the American Society for Nephrology, No. 11, Vol. 3, pp. 383393

Holland, G. N.; Cornell, P. J.; Park, M. S.; Barbetti, A.; Yuge, J.; Kreiger, A. E.; Kaplan, H. J.; Pepose, J. S.; Heckenlively, J. R.; Culbertson, W. W.; Terasaki. P. I. (1989). An association between acute retinal necrosis syndrome and HLA-DQw7 and phenotype Bw62, DR4. American Journal of Ophthalmology, Vol. 108, No. 4, pp. 370-374

Holland GN, Executive committee of the American uveitis society (1994). Standard diagnostic criteria for the acute retinal necrosis syndrome. American Journal of Ophthalmolo$g y$, Vol. 117, No. 5, pp. 663-667

Hüfner, K.; Horn, A.; Derfuss, T.; Glon, C.; Sinicina, I.; Arbusow, V.; Strupp, M.; Brandt, T.; Theil, D. (2009). Fewer latent herpes simplex virus type 1 and cytotoxic $T$ cells occur in the ophthalmic division than in the maxillary and mandibular divisions of the human trigeminal ganglion and nerve. Journal of Virology, Vol. 83, No. 8, pp. 3696-3703.

Huynh, T. H.; Johnson, M. W.; Comer, G. M.; Fish, D. N. (2008). Vitreous penetration of orally administered valacyclovir. American Journal of Ophthalmology, Vol. 145, No. 4, pp. 682-686

Ichikawa, T.; Sakai, J.; Yamauchi, Y.; Minoda, H.; Usui, M. (1997). A study of 44 patients with Kirisawa type uveitis. Nippon Ganka Gakkai Zasshi, Vol. 101, No. 3, pp. 243-247

Itoh, N.; Matsumura, N.; Ogi, A.; Nishide, T.; Imai, Y.; Kanai, H.; Ohno, S. (2000). High prevalence of herpes simplex virus type 2 in acute retinal necrosis syndrome associated with herpes simplex virus in Japan. American Journal of Ophthalmology, Vol. 129, No. 3, pp. 404-405

Katragadda, S.; Talluri, R. S.; Pal, D.; Mitra, A. K. (2005). Identification and characterization of a Na+-dependent neutral amino acid transporter, ASCT1, in rabbit corneal epithelial cell culture and rabbit cornea. Current Eye Research, Vol. 30, No. 11, pp. 989-1002

Khanna, K. M.; Lepisto, A. J.; Decman, V.; Hendricks, R. L. (2004). Immune control of herpes simplex virus during latency. Current Opinion in Immunology, Vol. 16, No. 4, pp. 463-469

Kijlstra, A.; Luyendijk, L.; Baarsma, G. S.; Rothova, A.; Schweitzer, C. M.; Timmerman, Z.; de Vries, J.; Breebaart, A. C. (1989). Aqueous humor analysis as a diagnostic tool in toxoplasma uveitis. International Ophthalmology, Vol. 13, No. 6, pp. 383-386 
Kijlstra, A.; van den Horn, G. J.; Luyendijk, L.; Baarsma, G. S.; Schweitzer, C. M.; Zaal, M. J.; Timmerman, Z.; Beintema, M.; Rothova, A. (1990). Laboratory tests in uveitis. New developments in the analysis of local antibody production. Documenta Ophthalmologica, Vol. 75, No. 3-4, pp. 225-231

Kim, C.; Yoon, Y. H. (2002). Unilateral acute retinal necrosis occurring 2 years after herpes simplex type 1 encephalitis. Ophthalmic Surgery, Lasers and Imaging, Vol. 33, No. 3, pp. $250-252$

Kittan, N. A.; Bergua, A.; Haupt, S.; Donhauser, N.; Schuster, P.; Korn, K.; Harrer, T.; Schmidt, B. (2007). Impaired plasmacytoid dendritic cell innate immune responses in patients with herpesvirus-associated acute retinal necrosis. Journal of Immunology, Vol. 179, No. 6, pp. 4219-30.

Knickelbein, J. E.; Khanna, K. M.; Yee, M. B.; Baty, C. J.; Kinchington, P. R.; Hendricks, R. L. (2008) Noncytotoxic lytic granule-mediated CD8+ T cell inhibition of HSV-1 reactivation from neuronal latency. Science, Vol. 322, No. 5899, pp. 268-271

Knox, C. M.; Chandler, D.; Short, G. A.; Margolis, T. P. (1998). Polymerase chain reactionbased assays of vitreous samples for the diagnosis of viral retinitis. Use in diagnostic dilemmas. Ophthalmology, Vol. 105, No. 1, pp. 37-44

Kychenthal, A.; Coombes, A.; Greenwood, J.; Pavesio, C.; Aylward, G. W. (2001). Bilateral acute retinal necrosis and herpes simplex type 2 encephalitis in a neonate. British Journal of Ophthalmology, Vol. 85, No. 5, pp. 629-630

Labetoulle, M.; Kucera, P.; Ugolini, G.; Lafay, F.; Frau, E.; Offret, H.; Flamand, A. (2000). Neuronal pathways for the propagation of herpes simplex virus type 1 from one retina to the other in a murine model. Journal of General Virology, Vol. 81, No. 5, pp. $1201-1210$

Lafferty, W. E.; Coombs, R. W.; Benedetti, J.; Critchlow, C.; Corey, L. (1987). Recurrences after oral and genital herpes simplex virus infection. Influence of site of infection and viral type. New England Journal of Medicine, Vol. 316, No. 23, 1444-1449

Lau, C. H.; Missotten, T.; Salzmann, J.; Lightman, S. L. (2007). Acute retinal necrosis features, management, and outcomes. Ophthalmology, Vol. 114, No. 4, pp. 756-762

Liesegang, T. J. (2001). Herpes simplex virus epidemiology and ocular importance. Cornea, Vol. 20, No. 1, pp. 1-13

Lorette, G.; Crochard, A.; Mimaud, V.; Wolkenstein, P.; Stalder, J. F.; El Hasnaoui, A. (2006). A survey on the prevalence of orofacial herpes in France: the INSTANT study. Journal of the American Academy of Dermatology, Vol. 55, No. 2, pp. 225-232

Maertzdorf, J.; van der Lelij, A.; Baarsma, G. S.; Osterhaus, A. D.; Verjans, G. M. (2001). Herpes simplex virus type 1 (HSV-1)-induced retinitis following herpes simplex encephalitis: indications for brain-to-eye transmission of HSV-1. Annals of Neurology, Vol. 49, No. 1, pp. 104-106

Malkin, J. E.; Morand, P.; Malvy, D.; Ly, T.D.; Chanzy, B.; de Labareyre, C.; El Hasnaoui,A.; Hercberg, S. (2002). Seroprevalence of HSV-1 and HSV-2 infection in the general French population. Sexually Transmitted Infections, Vol. 78, No. 3, 201-203

Malvy, D.; Ezzedine, K.; Lançon, F.; Halioua, B.; Rezvani, A.; Bertrais, S.; Chanzy, B.; Malkin, J. E.; Morand, P.; de Labareyre, C.; Hercberg, S.; El Hasnaoui, A. (2007). Epidemiology of orofacial herpes simplex virus infections in the general population in France: results of the HERPIMAX study. Journal of the European Academy of Dermatology and Venereology, Vol. 21, No. 10, pp. 1398-1403 
Matsuo, T.; Matsuo, N. (1991). HLA-DR9 associated with the severity of acute retinal necrosis syndrome. Ophthalmologica, Vol. 203, No. 3, pp. 133-137

Miyashita, E. M.; Yang, B.; Lam, K. M.; Crawford, D. H.; Thorley-Lawson, D. A. (1995). A novel form of Epstein-Barr virus latency in normal B cells in vivo. Cell, Vol. 80, No. 4, pp. 593-601

Morse, L. S.; Mizoguchi, M. (1995). Diagnosis and management of viral retinitis in the acute retinal necrosis syndrome. Seminars in Ophthalmology, Vol. 10, No. 1, pp. 28-41

Moshfeghi, D. M.; Dodds, E. M.; Couto, C. A.; Santos, C. I.; Nicholson, D. H.; Lowder, C. Y.; Davis, J. L. (2004). Diagnostic approaches to severe, atypical toxoplasmosis mimicking acute retinal necrosis. Ophthalmology, Vol. 111, No. 4, pp. 716-725

Mott, K. R.; Bresee, C. J.; Allen, S, J; Ben Mohamed, L.; Wechsler, S. L.; Ghiasi, H. (2009). Level of herpes simplex virus type 1 latency correlates with severity of corneal scarring and exhaustion of CD8+ T cells in trigeminal ganglia of latently infected mice. Journal of Virology, Vol. 83, No. 5, pp. 2246-2254

Muthiah, M. N.; Michaelides, M.; Child, C. S.; Mitchell, S. M. (2007). Acute retinal necrosis: a national population-based study to assess the incidence, methods of diagnosis, treatment strategies and outcomes in the UK. British Journal of Ophthalmology, Vol. 91, No. 11, pp. 1452-1455

O'Brien, J. J. ; Campoli-Richards, D. M. (1989). Acyclovir. An updated review of its antiviral activity, pharmacokinetic properties and therapeutic efficacy. Drugs, Vol. 37, No. 3, pp. 233-309

Ongkosuwito, J. V.; van der Lelij, A.; Bruinenberg, M.; Wienesen-van Doorn, M.; Feron, E. J.; Hoyng, C. B.; de Keizer, R. J.; Klok, A. M.; Kijlstra, A. (1998). Increased presence of Epstein-Barr virus DNA in ocular fluid samples from HIV negative immunocompromised patients with uveitis. British Journal of Ophthalmology, Vol. 82, No. 3, pp. $245-251$

Palay, D. A.; Sternberg, P. Jr.; Davis, J.; Lewis, H.; Holland, G. N.; Mieler, W. F.; Jabs, D. A.; Drews, C. (1991). Decrease in the risk of bilateral acute retinal necrosis by acyclovir therapy. American Journal of Ophthalmology, Vol. 112, No. 3, pp. 250-255

Pavésio, C. E.; Conrad, D. K.; McCluskey, P. J.; Mitchell, S. M.; Towler, H. M.; Lightman, S. (1997). Delayed acute retinal necrosis after herpetic encephalitis. British Journal of Ophthalmology, Vol. 81, No. 5, pp. 415-416

Paya, C.; Humar, A.; Dominguez, E.; Washburn, K.; Blumberg, E.; Alexander, B.; Freeman, R.; Heaton, N.; Pescovitz, M. D.; valganciclovir solid organ transplant study group (2004). Efficacy and safety of valganciclovir vs. oral ganciclovir for prevention of cytomegalovirus disease in solid organ transplant recipients. American Journal of Transplantation, Vol. 4, No. 4, pp. 611-620

Pepose, J. S.; Flowers, B.; Stewart, J. A.; Grose, C.; Levy, D. S.; Culbertson, W. W.; Kreiger, A. E. (1992). Herpesvirus antibody levels in the etiologic diagnosis of the acute retinal necrosis syndrome. American Journal of Ophthalmology, Vol. 113, No. 3, pp. 248-256

Pevenstein, S. R.; Williams, R. K.; McChesney, D.; Mont, E. K.; Smialek, J. E.; Straus, S. E. (1999). Quantitation of latent varicella-zoster virus and herpes simplex virus genomes in human trigeminal ganglia. Journal of Virology, Vol. 73, No. 12, pp. 1051410518

Phan, D. D.; Chin-Hong, P.; Lin, E. T.; Anderle, P.; Sadee, W.; Guglielmo, B. J. (2003). Intraand interindividual variabilities of valacyclovir oral bioavailability and effect of co- 
administration of an hPEPT1 inhibitor. Antimicrobial Agents and Chemotherapy, Vol. 47, No. 7, pp. 2351-2353

Pleyer, U.; Metzner, S.; Hofmann, J. (2009). Diagnostics and differential diagnosis of acute retinal necrosis. Ophthalmologe, Vol. 106, No. 12, pp. 1074-1082

Rahhal, F. M.; Siegel, L. M.; Russak, V.; Wiley, C. A.; Tedder, D. G.; Weinberg, A.; Rickman, L.; Freeman, W. R. (1996). Clinicopathologic correlations in acute retinal necrosis caused by herpes simplex virus type 2. Archives of Ophthalmology, Vol. 114, No. 11, pp. 1416-1419

Rautenberg, P.; Grančičova, L.; Hillenkamp, J.; Nölle, B.; Roider, J.; Fickenscher, H. (2009). Acute retinal necrosis from the virologist's perspective. Ophthalmologe, Vol. 106, No. 12, pp. 1065-1073

Reid, R.; Mar, E.C.; Huang, E. S.; Topal, M. D. (1988). Insertion and extension of acyclic, dideoxy, and ara nucleotides by herpesviridae, human alpha and human beta polymerases. A unique inhibition mechanism for 9-(1,3-dihydroxy-2-propoxymethyl)guanine triphosphate. Journal of Biological Chemistry, No. 263, No. 8, pp. 3898-3904

Rummelt, V.; Wenkel, H.; Rummelt, C.; Jahn, G.; Meyer, H. J.; Naumann, G. O. (1992). Detection of varicella zoster virus DNA and viral antigen in the late stage of bilateral acute retinal necrosis syndrome. Archives of Ophthalmology, Vol. 110, No. 8, 1132-1136

Saari, K. M.; Böke, W.; Manthey, K. F.; Algvere, P.; Hellquist, H.; Kättström, O.; Räsänen, O.; Paavola, M. (1982). Bilateral acute retinal necrosis. American Journal of Ophthalmology, Vol. 93, No. 4, pp. 403-411

Savant, V.; Saeed, T.; Denniston, A.; Murray, P. I. (2004). Oral valganciclovir treatment of varicella zoster virus acute retinal necrosis. Eye (London), Vol. 18, No. 5, pp. 544-545

Schlingemann, R. O.; Bruinenberg, M.; Wertheim-van Dillen, P.; Feron, E. (1996). Twenty years' delay of fellow eye involvement in herpes simplex virus type 2-associated bilateral acute retinal necrosis syndrome. American Journal of Ophthalmology, Vol. 122, No. 6, pp. 891-892

Scott, I. U.; Luu, K. M.; Davis, J. L. (2002). Intravitreal antivirals in the management of patients with aquired immunodeficiency syndrome with progressive outer retinal necrosis. Archives of Ophthalmology, Vol. 120, No. 9, pp. 1219-1222

Silverstein, B. E.; Conrad, D.; Margolis, T. P.; Wong, I. G. (1997). Cytomegalovirus-associated acute retinal necrosis syndrome. American Journal of Ophthalmology, Vol. 123, No. 2, pp. $257-258$

Sinclair, J. (2008). Human cytomegalovirus: Latency and reactivation in the myeloid lineage. Journal of Clinical Virology, Vol. 41, No. 3, pp. 180-185

Sinclair, J.; Sissons, P. (2006). Latency and reactivation of human cytomegalovirus. Journal of General Virology, Vol. 87, No. 7, pp. 1763-1779

Soul-Lawton, J.; Seaber, E.; On, N.; Wootton, R.; Rolan, P.; Posner, J. (1995). Absolute bioavailability and metabolic disposition of valaciclovir, the L-valyl ester of acyclovir, following oral administration to humans. Antimicrobial Agents and Chemotherapy, Vol. 39, No. 12, pp. 2759-2764

Steiner, I.; Kennedy, P. G.; Pachner, A. R. (2007). The neurotropic herpes viruses: herpes simplex and varicella-zoster. Lancet Neurology, Vol. 6, No. 11, pp. 1015-1028

Sugita, S.; Shimizu, N.; Watanabe, K.; Mizukami, M.; Morio,T.; Sugamoto, Y.; Mochizuki, M. (2008). Use of multiplex PCR and real-time PCR to detect human herpesvirus geno- 
me in ocular fluids of patients with uveitis. British Journal of Ophthalmology, Vol. 92, No. 7, pp. 928-932

Tajunisah, I.; Reddy, S. C.; Tan, L. H. (2009). Acute retinal necrosis by cytomegalovirus in an immunocompetent adult: case report and review of the literature. International Ophthalmology, Vol. 29, No. 2, pp. 85-90

Tam, P. M.; Hooper, C. Y.; Lightman, S. (2010). Antiviral selection in the management of acute retinal necrosis. Clinical Ophthalmology, Vol.4, pp. 11-20

Theil, D.; Derfuss, T.; Paripovic, I.; Herberger, S.; Meinl, E.; Schueler, O.; Strupp, M.; Arbusow, V.; Brandt, T. (2003). Latent herpesvirus infection in human trigeminal ganglia causes chronic immune response. American Journal of Pathology, Vol. 163, No. 6, pp. 2179-2184

Tibbetts, M. D.; Shah, C. P.; Young, L. H.; Duker, J. S.; Maguire, J. I.; Morley, M. G. (2010). Treatment of acute retinal necrosis. Ophthalmology, Vol. 117, No. 4, pp. 818-824

Tran, T. H.; Rozenberg, F.; Cassoux, N.; Rao, N. A.; LeHoang, P.; Bodaghi, B. (2003a). Polymerase chain reaction analysis of aqueous humour samples in necrotising retinitis. British Journal of Ophthalmology, Vol. 87, No. 1, pp. 79-83.

Tran, T. H.; Stanescu, D.; Caspers-Velu, L.; Rozenberg, F.; Liesnard, C.; Gaudric, A.; Lehoang, P.; Bodaghi, B. (2003b). Clinical characteristics of acute HSV-2 retinal necrosis. American Journal of Ophthalmology, Vol. 137, No. 5, pp. 872-879

Urayama, A.; Yamada, N.; Sasaki, T. (1971). Unilateral acute uveitis with periarteritis and detachment. Japanese Journal of Clinical Ophthalmology, Vol. 25, pp. 607-619

Usui, Y.; Takeuchi, M.; Goto, H.; Mori, H.; Kezuka, T.; Sakai, J.; Usui, M. (2008). Acute retinal necrosis in Japan. Ophthalmology, Vol. 115, No. 9, pp. 1632-1633

Vandercam, T.; Hintzen, R. Q.; de Boer, J. H.; van der Lelij, A. (2008). Herpetic encephalitis is a risk factor for acute retinal necrosis. Neurology, Vol. 71, No. 16, pp. 1268-1274

van Gelder, R. N.; Willig, J. L.; Holland, G. N.; Kaplan, H. J. (2001). Herpes simplex virus type 2 as a cause of acute retinal necrosis syndrome in young patients. Ophthalmology, Vol. 108, No. 5, pp. 869-876

Velez, G.; Roy, C. E.; Whitcup, S. M.; Chan, C. C.; Robinson, M. R. (2001). High-dose intravitreal ganciclovir and foscarnet for cytomegalovirus retinitis. American Journal of Ophthalmology, Vol. 131, No. 3, pp. 396-397

Voros, G. M.; Pandit, R.; Snow, M.; Griffiths, P. G. (2006). Unilateral recurrent acute retinal necrosis syndrome caused by cytomegalovirus in an immune-competent adult. European Journal of Ophthalmology, Vol. 16, No. 3, pp. 484-486

Winterhalter, S.; Adams, O.; Althaus, Ch.; Stammen, J.; Schöler, E. M.; Joussen, A. M. (2007). Acute retinal necrosis. Klinische Monatsblätter für Augenheilkunde, Vol. 224, No. 7, pp. 567-574

Yamamoto, S.; Nakao, T.; Kajiyama, K. (2007). Acute retinal necrosis following herpes simplex encephalitis. Archives of Neurology, Vol. 64, No. 2, pp. 283

Yamamoto, S.; Sugita, S.; Sugamoto, Y.; Shimizu, N.; Morio, T.; Mochizuki, M. (2008). Quantitative PCR for the detection of genomic DNA of Epstein-Barr virus in ocular fluids of patients with uveitis. Japanese Journal of Ophthalmology, Vol. 52, No. 6, pp. 463-467

Young, N. J.; Bird, A. C. (1978). Bilateral acute retinal necrosis. British Journal of Ophthalmology, Vol. 62, No. 9, pp. 581-590

Zambarakji, H. J.; Obi, A. A.; Mitchell, S. M. (2002). Successful treatment of varicella-zoster virus retinitis with aggressive intravitreal and systemic antiviral therapy. Ocular Immunology and Inflammation, Vol. 10, No. 1, pp. 41-46 


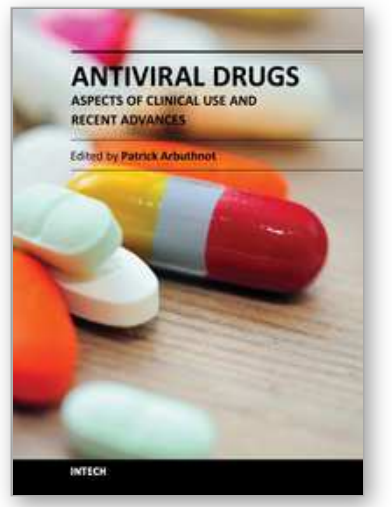

\author{
Antiviral Drugs - Aspects of Clinical Use and Recent Advances \\ Edited by Dr. Patrick Arbuthnot
}

ISBN 978-953-51-0256-4

Hard cover, 194 pages

Publisher InTech

Published online 14, March, 2012

Published in print edition March, 2012

The articles that appear in Antiviral Drugs - Aspects of Clinical Use and Recent Advances cover several topics that reflect the varied mechanisms of viral disease pathogenesis and treatment. Clinical management and new developments in the treatment of virus-related diseases are the two main sections of the book. The first part reviews the treatment of hepatitis $C$ virus infection, the management of virus-related acute retinal necrosis, the use of leflunomide therapy in renal transplant patients, and mathematical modeling of HIV-1 treatment responses. Basic research topics are dealt with in the second half of the book. New developments in the treatment of the influenza virus, the use of animal models for HIV-1 drug development, the use of single chain camelid antibodies against negative strand RNA viruses, countering norovirus infection, and the use of plant extracts to treat herpes simplex virus infection are described. The content of the book is not intended to be comprehensive, but aims to provide the reader with insights into selected aspects of established and new viral therapies.

\title{
How to reference
}

In order to correctly reference this scholarly work, feel free to copy and paste the following:

Peter Rautenberg, Jost Hillenkamp, Livia Grančičova, Bernhard Nölle, Johann Roider and Helmut Fickenscher (2012). Virus Diagnostics and Antiviral Therapy in Acute Retinal Necrosis (ARN), Antiviral Drugs - Aspects of Clinical Use and Recent Advances, Dr. Patrick Arbuthnot (Ed.), ISBN: 978-953-51-0256-4, InTech, Available from: http://www.intechopen.com/books/antiviral-drugs-aspects-of-clinical-use-and-recent-advances/virusdiagnostics-and-antiviral-therapy-in-acute-retinal-necrosis-

\section{INTECH}

open science | open minds

\section{InTech Europe}

University Campus STeP Ri

Slavka Krautzeka 83/A

51000 Rijeka, Croatia

Phone: +385 (51) 770447

Fax: +385 (51) 686166

www.intechopen.com

\section{InTech China}

Unit 405, Office Block, Hotel Equatorial Shanghai

No.65, Yan An Road (West), Shanghai, 200040, China 中国上海市延安西路65号上海国际贵都大饭店办公楼405单元

Phone: +86-21-62489820

Fax: +86-21-62489821 
(C) 2012 The Author(s). Licensee IntechOpen. This is an open access article distributed under the terms of the Creative Commons Attribution 3.0 License, which permits unrestricted use, distribution, and reproduction in any medium, provided the original work is properly cited. 